\title{
SUSTAINABLE PROJECT MANAGEMENT AND THE ROLE OF INTEGRATED COMMUNICATIONS (IC)
}

\author{
Marcus Stumpf ${ }^{1}$, Manfred Brandstätter ${ }^{2}$, Jana Borghoff ${ }^{3}$ \\ ${ }^{1,3}$ FOM Hochschule für Oekonomie und Management, University of Applied Sciences, Germany \\ ${ }^{2}$ Die Organisationsgestalter, Germany
}

\begin{abstract}
When research and development projects fail, it is basically due to insufficient - and thus non-sustainable - communication within and outside the project organization. The concept of Integrated Communications, which literature discusses as a principle of Sustainability Communications, provides approaches to more effectively master certain challenges of project communications. In this respect, literature argues, for example, that integration of contents, form, and timing, both within project communication and between project and corporate communication, is a prerequisite to ensuring companies are on the same page, hence consistent, when communicating about project contents. Taking the success factors of Integrated Communications identified in previous empirical studies as a starting point, this contribution will investigate, based on university projects, whether these factors can also be applied to project communications and to what extent they influence the success of project communications. Finally, the conclusion offers recommended action to facilitate sustainable project communications and provides recommendations for further research in this area.
\end{abstract}

Key words: integrated communications, project communications, project management, sustainability.

\section{PROJECT COMMUNICATION AS A SUCCESS FACTOR}

The starting point for the present research activities are the findings of studies and projects in the field of research and development which prove that projects irrespective of the industry- show a high failure percentage when it comes to meeting their original project goals. This is supported, amongst others, by two key findings of the socalled CHAOS report: Firstly, about $70 \%$ of the technology projects evaluated in the study did not reach their targets and exceeded their time and cost budgets. Secondly, the major factor by far that caused a project to fail was insufficient project communications. In their annual CHAOS report (cf. CHAOS, 2015, p. 2) the Standish Group International Inc., an international market research firm specializing in project management, presents the results of more than 40.000 international technology projects. One of the key findings of their study is a categorization of projects according to their success. It identifies three types of projects:
- Type 1 Projects (successful) - on time and on budget (29\%),

- Type 2 Projects (challenged) - on time or on budget (52\%),

- Type 3 Projects (failed)- over time and over budget or aborted (19\%).

The CHAOS report 2015 (cf. CHAOS, 2015) draws on findings of its 2011 equivalent. In addition to the categorization of success factors of Type 1 projects, the second aspect of the 2011 report (CHAOS, 2011) determines the failure factors of Type 2 and Type 3 projects. In the list of failure factors for type 2 and type 3 projects, communication is the dominating factor. The authors of the report identified a deficit in internal and external project communications. Internal communications denotes all communication activities between groups of people involved in the project. The groups of people involved in a project are further defined as the project members and contributors as well as the project manager and the internal project owner. In the context of project management, external communications refers to all 
communication activities between project members and their environment, such as media, the public, or contractors (cf. Camilleri, 2011, p. 269; IPMA-Baseline, 2009,p. 20;IPMA-Baseline, 2016, p. 90; PMBOK, 2013, chapter 10.1.2.1). These findings agree with those of Kerzner (2009), whose research on project communications specifically points to internal and external project communications as being key factors for the success or failure of projects (cf. Kerzner, 2009, p. 238).

The findings of the CHAOS report, which has been carried out regularly since 1998, are confirmed by a research study of the German Society of Project Management (cf. Engel, Menzer, \& Nienstedt, 2006), which also analysed research and development projects. The study identifies communication, in the sense of sustainable communication, within and outside the project organization as a crucial success factor. The study confirmed that, on average, $37 \%$ of all projects were considered as failed and $63 \%$ as successful. This evaluation of project success allows for a distinction between three types of companies:

- Top Companies: This category includes companies, which implement their projects at a success rate of at least $80 \%$.

- Standard Companies: The study categorized all companies as standard companies that implemented $50-80 \%$ of their projects successfully. According to the authors of the study these companies represent the current project practice.

- Low Companies: This category comprises companies that implement less than $50 \%$ of their projects successfully.

With regard to project communication the authors came up with the following findings:

- Top companies communicate professionally with the management through appropriate project reporting.

- Top companies regularly communicate the project contents and progress throughout the enterprise.

- In addition to established information channels, they use dialogue-oriented, interactive communication methods to a lesser extent.

- Low and Top Companies rarely set up a separate single person in charge of communication.

Another central finding of the study is that one of the main reasons for projects to fail is the lack of necessary communication activities in the start-up phase of a project (e.g. periodic consultation and coordination between internal and external owners at an early project stage as well as early involvement of the project manager, or the implementation of necessary monitoring processes) (cf. IPMA-Baseline, 2016, p. 45; PMBOK, 2013, chapter 10.1).

Further studies have finally shown that many project managers consider communication within and outside the project organization to be of rather subordinate importance (cf. Danturthi, 2016). Litke and Kunow (2008) conclude in their papers that the reasons for insufficient project communication stem from an unclear definition of target groups, statement of requirements, and choice of communication procedures as well as means of communication. Moreover, they list 'transparent communication', i.e. a standardized approach to structuring contents, procedures and behaviour in project communication, as a factor for success. In summary, there can be said to be a high correlation between communication behaviour and the (long-term) success of a project (cf. Brebbia, \& Beriatos, 2011, p. 530; Danturthi, 2016; PMBOK, 2013, chapter 10.1).

\section{SUSTAINABILITY COMMUNICATIONS AND INTEGRATION}

In order to describe the nature of sustainable communications in a more detailed way, some related concepts will be discussed in the following. The concept of sustainability is generally understood to consist of three components, also known as the Three Pillars of Sustainability (cf. Brebbia, \& Beriatos, 2011, p. 527):

- Ecological sustainability stands for the striving to preserve nature and the environment for future generations. 
- Economic sustainability describes the economic model that forms a continuous and sustainable basis for commerce and prosperity.

- The result of social sustainability is a society that enables all its members to contribute their share toward creating a stable society that is fit for the future and worth living in.

A functioning ecological, social and economic system - one which preserves the natural basis of life and in which social solidarity and economic productivity are considered equally important - is thus to be passed on to future generations (cf. Brebbia, \& Beriatos, 2011, p. 527). The term sustainability originally derives from the verb "to sustain" - to keep up (Merriam Webster Dictionary, 2018b) and the noun "ability" - the quality or state of being able (Merriam Webster Dictionary, 2018a) - and is therefore understood as "the ability to keep something up". According to the "Report of the World Commission on Environment and Development", sustainability is defined as a "[...] development that meets the needs of the present without compromising the ability of future generations to meet their own needs" (United Nations, 1987, chapter 2).

From the combination of the concepts 'sustainability' and 'communication' (in a marketing related sense) results the concept of sustainability communications, which will be discussed in the following. Godemann and Michelsen (2011) define the concept generally as a global societal process (accompanied by mass media) consisting of the recursive arrangement of contributions and arguments for a better life in ecological, economic and social terms (cf. Godemann, \& Michelsen, 2011, p. 10). Using the field of marketing as an example, Schulz, Hörschgen, Kirstein, Kreeb, \& Motzer (2008, p. 34) illustrate the need to distinguish between two kinds of sustainability communications: Sustainability communications as defined above, and sustainable communication that refers to a 'sustained' effect of communication instruments and which communicates in a sustainable - i.e. resource efficient - way (cf. also Genç, 2017).The present contribution focuses on the latter. Economic activities -in this particular case, communications - are thus understood as sustainable, when they are conducted with a long-term focus, i.e. a positive influence on the company or project over a long period of time. (cf. e.g. Brebbia, \& Beriatos, 2011, p. 528).

Numerous authors (cf. e.g. Godemann, \& Michelsen, 2011, p. 47) point to integration, in its various manifestations, as an important principle of sustainability communications. From the viewpoint of sustainability communications, integration does indeed play an important role in several respects. Firstly, due to its integrated perspective of economic, social and ecological aspects, the sustainability concept in itself includes an integration component. Secondly, sustainability communications is not a standalone subfield of Public Relations such as internal communications, media relations, investor relations, or educational relations but rather a field of tasks and topics that, fulfilling an interdisciplinary function, is integrated into various programs according to the situation at hand. In addition, controversial topics, like those related to sustainability, require a symmetric and dialogue-oriented form of communication; one in which the concerns of external stakeholders are passed to the inside - and integrated into the decision-making processes - of the company. To summarize, this shows that integration-oriented communications does indeed offer aspects that clearly tie in with sustainability communications.

\section{INTEGRATION-ORIENTED COMMUNICATION APPROACHES}

Increasingly saturated markets, an ever growing diversity of brands within product fields as well as a conspicuous homogeneity of products have made companies today compete by way of communication rather than products. At the same time, the available media as well as the variety of communication instruments used have multiplied to such an extent that an atomization of media can be said to have occurred, which, in turn, lead to an information overload for consumers. Moreover, the resulting reactance effects are magnified by conflicting corporate communications if the messages conveyed via 
different media are inconsistent. These developments in the communication and media markets give an idea of the challenges companies face in their communication efforts. Against this background, the need for Integrated Communications has been emphasized for years and has also been discussed intensively both in conceptional research (e.g. Blakeman, 2018; Bruhn \& Schnebelen, 2017; Caywood, 2012; Ewing, 2009; Hackley, 2010; Mulhern, 2009; Schultz, Patti, \& Kitchen, 2011) and in practice. It has also given rise to the argument that through a more intense coordination of all communication activities, a company can achieve a more effective and efficient presentation of its image to the public, customers, staff and other target groups (cf. Bruhn \& Schnebelen, 2017,p. 466).

The following will discuss the Approach of Integrated Communications according to Bruhn, which provides concrete starting points for putting Integrated Communication into practice. Bruhn's approach of Integrated Communications differs from the above approach of sustainability communications in that it is strongly oriented towards marketing and focuses on management, staff, and customers, as target groups. Still, the concept provides approaches that help master certain challenges of sustainability communications, e.g. sustainability communications in multinational companies or challenges due to credibility problems.

Bruhn's approach is rooted in the findings of the Gestalt psychology, which, summarized in short, states that it is difficult to perceive a consistent message in the face of conflicting or inconsistent information. Reversing the argument, Bruhn claims that corporate communications need to be implemented in a consistent way. According to Bruhn, this necessitates Integrated Communications, which he defines as a strategic and operational process, comprising analysis, planning, organization, implementation and monitoring, that aims to harmonize the different sources of internal and external communications of companies, to provide the target groups of such communication with a consistent image of the company, or the object of reference (cf. Bruhn, \& Schnebelen, 2017, p. 466).

\section{RESEARCH INTEREST AND EMPIRICAL METHOD}

Based on the definition of project management, projects can be defined as 'temporary enterprises' (cf. Brebbia, \& Beriatos, 2011, p. 529; Camilleri, 2011, p. 4; IPMA-Baseline, 2016, p. 33; Grün, 2004, p. 182; Popkova, Sukhova, Rogachev, Tyuirna, Boris, \& Parakhina, 2017, p. 14). Proceeding on this definition and considering the definitions of sustainable communications outlined in previous chapters as well as the discussion of Integrated Communications as a principle of Sustainability Communications, the question arises whether there exists a positive correlation between Integrated Communications and sustainable project success.

In order to answer this research question, concluded student projects of applied research conducted at the business school of the Salzburg University of Applied Sciences were analyzed in the form of a study. From late summer to fall 2011 a quantitative complete survey was carried out with 18 project managers via an online questionnaire. At a return rate of $83.3 \%, \mathrm{~N}=15$ questionnaires could finally be considered. The questions asked were based on previously identified success factors of Integrated Communications (cf. Stumpf, 2005). These were adapted to the research interest - project management - and phrased as follows:

- Project manager invigorates communication: The project manager increases the motivation of the project team by making systematic use of communication. $\mathrm{He}$ acts as a role model for communication within and outside the project.

- Communication framework: Communication guidelines in terms of objectives, target groups, contents, form, and frequency of communication are provided.

- Monitoring of communication framework: Communication is validated against its objectives, target groups, contents, form and frequency.

- Project environment analysis: The communication environment is analyzed internally and externally. 
- Consistency of communication contents: Available information is identical, without variations in content, as regards objectives, target groups, strategies, instruments, activities and messages.

- Consistent visual appearance: The visual identity of the communication is in line with the communication purpose (e.g. the layout of all information provided to the neighbours of a building project follows the corporate design of the contractor; its content is standardized in terms of structure and wording).

- Productive exchange of information: The exchange of information between internal and external project members takes place effectively and efficiently with regard to expectations (e.g. to enable the assessment of performance progress, the project manager provides the project owner with a status report showing performance, due dates and expenses on a given reporting date, according to a simple traffic light status; any further information is sparingly summarized on a separate letter-size sheet).

- Common understanding of the relevance of communication: The project team understands the importance of a standardized communication concept and of internal communication.

- Project organization supports communication: The project organization provides a consistent operating structure (roles, responsibilities, processes) where care is taken to ensure information flows in the form of a well balanced mix of formal and informal communication.

- One person in charge of communications: One person or a group of persons is in charge of all internal and external communications of the project.

Apart from inquiring into the existence of the above-mentioned criteria, the study also evaluated the primary effects of the respondents' project management and the success of their projects. According to the definition of traditional project management, project success is based on the project's completion within the allocated time period, the budgeted cost and at the proper performance or specification level, amongst other factors (cf. Camilleri, 2011, p. 6 and p. 13; Kerzner, 2009, p. 7). These effects then denote the aspects that a) describe the scope of a project, b) were defined in the planning phase and c) are to be kept unchanged, or changed only minimally, throughout the implementation of the project (cf. ICB, 2009; IPMA-Baseline, 2009). In this context, project success is defined as meeting the primary project targets. These are performance targets (defined functional scope), time targets (adherence to timetables) and cost targets (meeting performance and time targets while adhering to the budgeted costs). Hence, a project is considered a success if these primary goals are met partly or wholly. The degree of project success is determined by the degree to which the primary goals are achieved (cf. Kerzner, 2009, p. 7)

\section{DATA ANALYSIS AND RESEARCH FINDINGS}

The results of the survey were analyzed using the Partial Least Squares (PLS) path analysis (for further information on PLS cf. e.g. Esposito Vinzi, Chin, Henseler, \& Wang, 2010; Hengky \& Noonan, 2017). To calculate the required model, the statistical application software SmartPLS 2.0 was used (cf. Ringle, Wende, \& Will, 2005). The PLS procedure is mainly applied if - as is the case in the present study - small samples have to be used, as the PLS path analysis is an iterative estimation method which defines the required number of cases according to the largest regression analysis within the model. Literature suggests, for this purpose, a heuristic approach, to arrive at the minimum sample size by multiplying the maximum number of indicators to be assessed by five to ten. Given the performance stability construct with three indicators of project success, the minimum number required for the present study would then be 15 to 30 cases. Hence, with $\mathrm{N}=15$ the minimum requirement for the present survey is just met.

The results of the analysis (which are mapped in figure 1 in the form of estimates of the path 
coefficients between the different constructs), the results of the significance tests through bootstrapping (which are given in brackets), as well as the four determination coefficients of the latent endogenous variables, make it possible to assess the quality of the assumed structure of the estimated model.

The analysis of the data reveals that three of the steps of Integrated Communications project manager invigorates communication, project environment analysis, and productive exchange of information - represent the only independent constructs that have statistically significant influence on the performance, cost, and timetable stability constructs. For this reason, figure 1 focuses on these constructs. A further analysis of the findings supports the assumption propagated in literature (cf. Christensen, Fuat Firat, \& Moberg Torp, 2008 , on management's role in invigorating communication in the context of integrated communication; on the consideration of environmental factors in this context cf. e.g. Camilleri, 2018, p. 85; on project communication as a success factor in general cf. also chapter 1 of this article) that these project effects influence the success of a project in a statistically significant way.

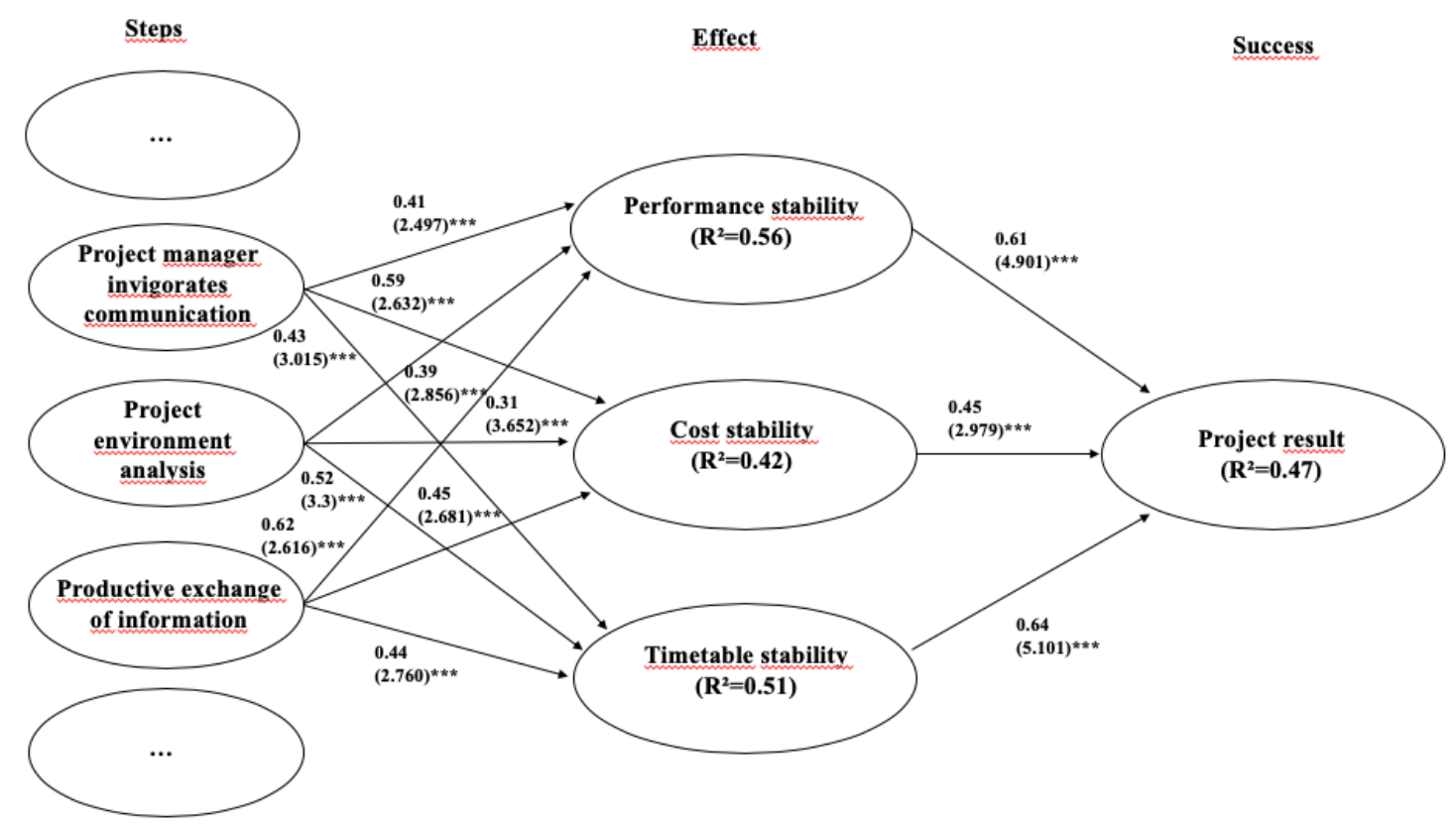

Results for the comprehensive identification model $(\mathrm{N}=15)$ : Determined using smartPLS 2.0

(Ringle et al., 2005). Significance test through bootstrapping with 100 iterations; *: p 0.05

(critical value 1.895); **: p 0.01 (critical value 2.475); ***: p 0.001 (critical value 3.310).

Figure 1: Measurement results of the PLS path model $(\mathrm{N}=15)$ (source: own illustration)

In line with recommendations by literature the evaluation of reflective measurement models in PLS is carried out according to the following quality criteria: content validity, indicator reliability, construct reliability, and discriminant validity (cf. Campos, Graham, Jorge, Nunes, Palanque, \& Winckler, 2011, p. 384). The content validity evaluates the extent to which the variables of a measurement model correspond with the content of the construct. In the present study, this was ensured by applying established scales. The indicator reliability is assessed by evaluating the factor loading of the respective indicators.
In general, $50 \%$ of the indicator variance needs to be explained by the respective construct, which results in a factor loading of $0.7(0.7=$ square root of 0.5$)$ (for basic information on Cronbach's alpha cf. e.g. Cronbach, 1951; Cortina, 1993). In addition, the quality of how well the construct was measured by the indicators assigned to it was evaluated by means of the construct reliability, which requires the indicators that refer to the same construct to correlate strongly with one another. The construct reliability was verified through its internal consistency and Cronbach's alpha. For both 
criteria, indicator values higher than 0.7 are assumed as acceptable (cf. Nunnally, 1978, p. 245).Tab. 1 shows that all values of internal consistency as well as Cronbach's alpha of all constructs exceed this minimum value.

Lastly, the discriminant validity was verified by means of the Average Variance Extracted (AVE). The AVE measures to which extent the latent variables represent independent constructs. In order to evaluate the constructs of the present study, the FornellLarckerCriterion was applied (cf. Fornell, \& Larcker, 1981, p.45). According to this criterion, discriminant validity exists if the AVE of the respective latent construct (here: project success) is higher than all squared correlations between such construct and any other latent construct of the research model (AVE > squared correlation). The present correlation matrix exhibits a low correlation between the cost stability and project success constructs of 0.24 , a slightly higher correlation of 0.39 between performance stability and project success, and of 0.44 between timetable stability and project success. From this results: AVE project success $=0.69>$ performance stability $\mathrm{r} 2=$ 0.0576, AVE project success $=0.69>$ cost stability $\mathrm{r} 2=0.1521$ and AVE project success $=0.69>$ timetable stability $\mathrm{r} 2=0.1936$. In conclusion it can be summarized that within this model a discriminant validity is proven and that the quality of the model is acceptable throughout all quality criteria.

Table 1: Quality criteria for the PLS model ( $=15)$ (source: own illustration)

\begin{tabular}{|c|c|c|c|}
\hline \multirow[b]{2}{*}{$\begin{array}{l}\text { Model Identification } \\
\qquad \mathrm{N}=15\end{array}$} & \multicolumn{3}{|c|}{ Measurement Model Evaluation } \\
\hline & $\begin{array}{l}\text { Validity: } \\
\text { Average Variance Extracted } \\
\text { (AVE) }\end{array}$ & $\begin{array}{l}\text { Construct Reliability: } \\
\text { Internal Consistency/ } \\
\text { Composite Reliability }\end{array}$ & $\begin{array}{l}\text { Construct Reliability: } \\
\text { Cronbach's Alpha }\end{array}$ \\
\hline Project Manager invigorates communication & 0.69 & 0.83 & 0.77 \\
\hline Project environment analysis & 0.63 & 0.86 & 0.82 \\
\hline Productive exchange of information & 1.00 & 1.00 & 1.00 \\
\hline Performance stability & 0.61 & 0.90 & 0.87 \\
\hline Cost stability & 0.72 & 0.71 & 0.81 \\
\hline Timetable stability & 0.62 & 0.78 & 0.86 \\
\hline Project success & 0.69 & 0.71 & 0.74 \\
\hline Minimum value & 0.6 & 0.7 & 0.7 \\
\hline
\end{tabular}

\section{CONCLUSION AND RECOMMENDED ACTION}

The aim of the present contribution was to analyze the correlation between communication activities/communication behaviour and the success of a project. The findings confirm that in the analyzed projects the following Integrated Communications activities correlate with the project targets:

- Project manager invigorates communication

- Project environment analysis

- Productive exchange of information.
Accordingly, the findings of this study suggest several recommended activities, which should be included as recommendations in the next issue of the regional White Papers of the International Project Management Association (IPMA). In essence, these White Papers - the papers of the IPMA being favored in this case as they are better established in Europe than those of the Project Management Institute (PMI) - are intended as recommendations for the introduction and implementation of project management within companies. The standards described in these papers result from thousands of project findings and are 
described as Best Practices by experts. Furthermore, they are updated and reissued every three to six years.

Regarding the main findings of the present study - 'project manager invigorates communication', 'project environment analysis' and 'productive exchange of information' - the authors of this article formulated the following recommendations for action:

\section{Project manager invigorates communication}

The first conclusion that is drawn from the present study is the necessity to place a greater emphasis on the project manager's role as the person in charge of communication. This can be achieved by expanding the project manager's job description in terms of communication responsibility, with the latter being a nondelegable responsibility. In current literature, the project manager's role is defined with a focus on leadership and management accounting. The communication aspect has to date been of minor importance and remains frequently neglected for various reasons by managers in the context of project management (cf. Kerzner, 2017, p. 155; ICB, 2009; IPMA-Baseline, 2009, p. 4).

\section{Project environment analysis}

The second aspect identified by the present study is the importance of the project environment analysis (PEA). The project environment analysis (PEA) should be recommended as an instrument for sustainable communication management of projects (cf. IPMA-Baseline, 2009, p.18). Currently, the PEA is applied as an instrument in project planning, to identify potential risks related to the stakeholders of a project and the influences and threats they represent (cf. e.g. Patzak, \& Rattay, 2012,p. 38.). The PEA in its updated form would, however, gain importance if applied as an instrument to identify the target groups, contents, procedures and tools of communication (cf. Kuster, Huber, Lippmann, Schmid, Schneider, Witschi, \& Wüst, 2015, p. 191 and p. 217; PMBOK, 2008). The present paper thus, first and foremost, aims to complement an existing instrument within the IPMA-Baseline White Papers (cf. IPMA-Baseline, 2016, p. 36).

\section{Productive exchange of information}

With regard to the third aspect established by the study, 'productive exchange of information', the findings suggest to use a project communication matrix as a new instrument in communication planning. The project communication matrix is a graphic representation that links different communication groups as well as communication contents within a project. It serves to contrast target groups, communication contents, methods and frequency. This very simple, yet effective, grid provides an overview of who should communicate with whom, when and how, already at the planning stage of a project (see Table 2 for an example). 
Table 2: Simple example of a communication matrix (source: own illustration)

\begin{tabular}{|c|c|c|c|c|}
\hline What & When & Who & How & Documents \\
\hline Start-up & Start of project & $\begin{array}{l}\text { Project owner, project } \\
\text { manager, team }\end{array}$ & Info meeting & Project assignment \\
\hline Planning & Planning phase & Project manager, team & Workshop & Minutes, project manual \\
\hline Progress Report & $\begin{array}{l}\text { Periodically (monthly or } \\
\text { as needed) }\end{array}$ & $\begin{array}{c}\text { Project owner, project } \\
\text { manager }\end{array}$ & Info meeting & Minutes, project manual \\
\hline Progress Report & Weekly & $\begin{array}{c}\text { Project Manager, task } \\
\text { manager }\end{array}$ & & \\
\hline Closing & Project closure & $\begin{array}{l}\text { Project owner, project } \\
\text { manager, team, users }\end{array}$ & Info meeting, minutes & $\begin{array}{l}\text { Minutes, documented } \\
\text { results, project manual }\end{array}$ \\
\hline
\end{tabular}

With respect to the research interest of whether the success factors of Integrated Communications can be applied to project communications and of whether project communications and project success are interrelated, we can draw the following conclusions: It is recommendable to make use of Integrated Communications as a basis for optimizing sustainable project communications. Projects have shown that the application of certain Integrated Communications activities highly correlates with project success.

What nevertheless remains unclear to this point is the role of digitalization and digital transformation, especially in the realm of (social) media und mobile technology, regarding the sustainable effect of integrated communications within projects. With respect to the limitations of this paper and with an eye on further research, the authors of this article suggest the inclusion of digital development and transformation processes into the field of project communication in further research projects, e.g. in studies designed and executed by students like in the one at hand. With a critical view on the worldwide development of (marketing) communications, the power of manifold digitalization and digital transformation processes should not be neglected and therefore be part of ongoing research in this area. A conceivable research question might thus be: "To what extent do processes of ongoing digitalization and digital transformation influence the sustainable effects of Integrated Communications within projects and their management?"

Furthermore (as digitalization goes hand in hand with internationalization) the aspect of internationalization of R\&D projects, especially in connection with the findings of the present study, has not been addressed in detail so far. While some branches of industry and commerce still are rather untouched by internationalisation und thus remain local, (both with respect to their cultural surrounding as well as the language used) projects, which require sustainable project communications (as the R\&D projects described in this article), are most often intercultural, international and inter-lingual. To address sustainable effects of project communication (making use of an integrated approach) might require further research focussing on cultural, national and linguistic aspects of project teams, their particularities and challenges.

In any case, the authors of this article recommend further research activities concerning the role of Integrated Communications within sustainable project management, as it constitutes a productive object of research, not only for project management studies themselves, but also for sustainability studies and interrelated branches of linguistics. 


\section{REFERENCES}

Blakeman, R. (2018). Integrated Marketing Communication - Creative Strategy from Idea to Implementation. Lanham et. al.: Rowman \& Littlefield.

Brebbia, C. A., \& Beriatos, E. (2011). Sustainable Development and Planning $V$. Ashurst: WIT Press.

Bruhn, M., \& Schnebelen, S. (2017). Integrated marketing communication from an instrumental to a customercentric perspective. European Journal of Marketing, 51(3), 464-489.

Camilleri, E. (2011). Project Success Critical Factors and Behaviours. Farnham: Gower.

Camilleri, M. A. (2018). Integrated Marketing Communications. In Travel Marketing, Tourism Economics and the Airline Product. Cham, Switzerland: Springer Nature, (Chapter 5, p. 85-103).

Campos, P., Graham, N., Jorge, J., Nunes, N., Palanque, P., \& Winckler, M. (eds.) (2011). Human-Computer Interaction: INTERACT 2011: 13th IFIP TC 13 International Conference, Lisbon, Portugal, September 5-9, 2011, Proceedings, Part III. Wiesbaden: Springer.

Caywood, C. L. (2012). The Handbook of Strategic Public Relations and Integrated Marketing Communications, $2^{\text {nd }}$ Edition, New York: McGraw Hill Professional.

Cortina, J. M. (1993). What Is Coefficient Alpha? An Examination of Theory and Applications. Journal of Applied Psychology. 78(1), 98-104.

CHAOS. (2015). "CHAOS Report 2015". Retrieved from https://www.standishgroup.com/sample_ research_files/CHAOSReport2015Final.pdf . [03.01.2019].

CHAOS. (2011). "CHAOS Report 2011". Retrieved from http://standishgroup.com/newsroom/chao s_manifesto_2011.php. [10.11.2011].

Christensen, L. T., Fuat Firat, A., \& Moberg Torp, S. (2008). The Organisation of Integrated Communications: Toward Flexible Integration. European Journal of Marketing. 42(3/4), 423-452.
Cronbach, L. J. (1951). Coefficient alpha and the internal structure of tests. Psychometrika, 16, 297-334.

Danturthi, R. S. (2016). Transparency in Project Management. Retrieved from www.projectmanagement.com/articles/35 8236/Transparency-in-ProjectManagement .[17.11.2018].

Engel, C., Menzer, M., \& Nienstedt, D.(2006).GPM/PA-Studie. Nürnberg: Deutsche Gesellschaft für Projektmanagement (GPM).

Esposito Vinzi, V., Chin, W. W., Henseler, J., \& Wang, H. (2010). Handbook of Partial Least Squares - Concepts, Methods and Applications. Heidelberg et. al.: Springer.

Ewing, M. T. (2009). Integrated marketing communications measurement and evaluation. Journal of marketing communications. 15(2-3), 103-117.

Fornell, C., \& Larcker, D.(1981). Evaluating Structural Equation Models with Unobservable Variables and Measurement Error. Journal of Marketing Research. 48(1), 39-50.

Genç, R. (2017). The Importance of Communication in Sustainability \& Sustainable Strategies. Procedia Manufacturing 8, 511 - 516.

Godemann, J., \& Michelsen, G. (2011). Sustainability Communication Interdisciplinary Perspectives and Theoretical Foundations. Dortrecht et. al.: Springer.

Grün, O. (2004). Taming Giant Projects. Berlin, Heidelberg, New York: Springer.

Hackley, C. (2010). Advertising \& Promotion - An Integrated Marketing Communications Approach. Los Angeles et. al.: Sage.

Hengky, L., \& Noonan, R. (2017). Partial Least Squares Path Modelling: Basic Concepts, Methodological Issues and Applications.Basel: Springer International Publishing AG.

ICB. (2009). IPMA Competence Baseline Version 3.0. Retrieved fromhttp://www.p-m-a.at/ICBpmbaseline- und-pm-basicsyllabus/View-category.html.

[30.11.2011]. 
IPMA-Baseline. (2016). Project Excellence Baseline for Achieving Excellence in Projects and Programmes. Retrieved from

https://www.ipma.world/projects/standar d/ . [03.01.2019].

IPMA-Baseline. (2009). IPMA Project management Baseline Version 3.0. Retrieved fromhttp://www.p-m-a.at/ICBpm-baseline-und-pm-basicsyllabus/View-category.html. [30.11.2011].

Kerzner, H. (2017). Project Management - A Systems Approach to Planning, Scheduling and Controlling. Hoboken, New Jersey: Wiley.

Kerzner, H. (2009). Project Management - A Systems Approach to Planning, Scheduling and Controlling. Hoboken, New Jersey: Wiley.

Kuster, J., Huber, E., Lippmann, R., Schmid, A., Schneider, E., Witschi, U., \& Wüst, R. (2015). Project Management Handbook. Heidelberg et. al: Springer.

Litke, H., \& Kunow, I. (2008). Projektmanagement. München: StS.

Merriam Webster Dictionary (2018a). "ability". Retrieved. https://www.merriamwebster.com/dictionary/ability. [02.11.2018].

Merriam Webster Dictionary (2018b). "sustain". Retrieved from https://www.merriamwebster.com/dictionary/sustain [02.11.2018].

Mulhern, F. (2009). Integrated marketing communications: From media channels to digital connectivity. Journal of marketing communications. 15(2-3), 85101.

Nunnally, J. C. (1978). Psychometric theory. 2nd edition, New York: McGraw-Hill.

Patzak, G., \& Rattay, G. (2012). Project Management: Guideline for the
Management of Projects, Project Portfolios, programs and Projectoriented Companies. Wien: Linde International.

PMBOK Guide. (2013). A Guide for the Project Management Body of Knowledge. Fifth Edition. Pennsylvania: Project Management Institute.

PMBOK. (2008). A Guide of the Project Management Body of Knowledge. Washington: Project Management Institute.

Popkova, E. G., Sukhova, V. E., Rogachev, A. F., Tyuirna, Y. G., Boris, O. A., \& Parakhina, V. N. (2017). Integration and Clustering for Sustainable Economic Growth. Cham: Springer International Publishing.

Ringle, C., Wende, S., \& Will, A. (2005). SmartPLS $2.0 \quad$ (beta). Retrieved fromhttp://www.smartpls.de. Hamburg [14.06.2012].

Schultz, D., Patti, C., \& Kitchen, P. (2011). The Evolution of Integrated Marketing Communications. Abingdon: Routledge.

Schulz, W., Hörschgen, H., Kirstein, S., Kreeb, M., \& Motzer, M. (2008). Nachhaltigkeitsmarketing: Sachstand und Perspektiven. In Schwender, C., Schulz, W. F., Kreeb, M. (ed.) Medialisierung der Nachhaltigkeit. Marburg: Metropolis.

Stumpf, M. (2005). Erfolgskontrolle der Integrierten Kommunikation: Messung des Entwicklungsstandes der Integrierten Kommunikation in Unternehmen.Wiesbaden: Gabler.

United Nations (1987). Report of the World Commission on Environment and Development

"Our Common Future". Retrieved from http://www.un-documents.net/ocf-02.htm [11.12.2018]. 